\title{
Unicentric study of cell therapy in chronic obstructive pulmonary disease/pulmonary emphysema
}

This article was published in the following Dove Press journal:

International Journal of COPD

I I January 20 I I

Number of times this article has been viewed

\author{
João Tadeu Ribeiro-Paes' \\ Aldemir Bilaqui ${ }^{2}$ \\ Oswaldo T Greco² \\ Milton Artur Ruiz ${ }^{2}$ \\ Monica Y Marcelino 3 \\ Talita Stessuk' \\ Carolina A de Faria ${ }^{3}$ \\ Mario R Lago ${ }^{2}$ \\ 'Universidade Estadual Paulista \\ (UNESP), Campus de Assis, Assis, \\ SP, Brazil; ${ }^{2}$ Cardiovascular Diseases \\ Institute (IMC), São José do Rio Preto, \\ SP, Brazil; ${ }^{3}$ Inter-units Biotechnology \\ Post Graduation Program, USP-IPT-I, \\ Butantan, São Paulo, SP, Brazil
}

\begin{abstract}
Within the chronic obstructive pulmonary disease (COPD) spectrum, lung emphysema presents, as a primarily histopathologic feature, the destruction of pulmonary parenchyma and, accordingly, an increase in the airflow obstruction distal to the terminal bronchiole. Notwithstanding the significant advances in prevention and treatment of symptoms, no effective or curative therapy has been accomplished. In this context, cellular therapy with stem cells (SCs) arises as a new therapeutic approach, with a wide application potential. The purpose of this study is to evaluate the safety of SCs infusion procedure in patients with advanced COPD (stage IV dyspnea). After selection, patients underwent clinical examination and received granulocyte colony-stimulating factor, immediately prior to the bone marrow harvest. The bone marrow mononuclear cells (BMMC) were isolated and infused into a peripheral vein. The 12-month follow-up showed a significant improvement in the quality of life, as well as a clinical stable condition, which suggest a change in the natural process of the disease. Therefore, the proposed methodology in this study for BMMC cell therapy in sufferers of advanced COPD was demonstrated to be free of significant adverse effects. Although a larger sample and a greater follow-up period are needed, it is possible to infer that BMMC cell therapy introduces an unprecedented change in the course or in the natural history of emphysema, inhibiting or slowing the progression of disease. This clinical trial was registered with ClinicalTrials.gov (NCT01110252) and was approved by the Brazilian National Committee of Ethics in Research (registration no. 14764, CONEP report 233/2009).
\end{abstract}

Keywords: cell therapy, chronic obstructive pulmonary disease COPD, pulmonary emphysema, BMMC, stem cells

\section{Introduction}

Chronic obstructive pulmonary disease (COPD) may be defined as a pathological state characterized by gradual, chronic, and nonreversible airflow impairment. This limitation is associated with the abnormal inflammatory response of the lungs to the inhalation of particles and/or toxic gases. The main symptoms associated with the pathology are chronic and progressive dyspnea and productive cough. ${ }^{1,2}$

COPD is a public health problem worldwide, with high prevalence and significant economic and social impact. ${ }^{2-5}$ According to recent World Health Organization data, the global prevalence of COPD was estimated to be approximately 210 million individuals, with 80 million ranking among the moderate and/or severe stage of the disease. Currently, it is the fifth chief cause of death; however, estimates put it in the third rank by 2030, primarily due to exposure to risk factors, especially to cigarette smoke. ${ }^{1}$

Within the COPD spectrum, the most relevant feature in the lung emphysema is airflow limitation, resulting from the loss of alveolar wall and enlargement of alveolar
Correspondence: João Tadeu Ribeiro-Paes Department of Biological Sciences, Universidade Estadual Paulista,Av. Dom Antonio, 2100,Assis, 19806-900 SP, Brazil Tel +55 I8 33025856

Email jtrpaes@yahoo.com.br 
space distal to the terminal bronchiole. ${ }^{1,2,6,7}$ In spite of the advances in the prevention and treatment of the symptoms, no effective therapy has been accomplished till now. None of the advancements has enabled the reduction of the disease progression.

Considering all these aspects, the epidemiological data and the social impact associated with this pathological condition, several experimental models have been proposed aiming to increase the knowledge of the physiopathological processes and expand the options for COPD treatment. ${ }^{2,8-18}$

In this context, cellular therapy (CT) with stem cells (SCs) arises as a new therapeutic approach, with a wide application potential. A wide range of literature exists indicating promising results and therapeutic outlooks with adult and embryonic SCs for organ regeneration and repair, including pulmonary tissue. ${ }^{16-27}$

Notwithstanding the lack of consistent data on the SC homing mechanism, a set of experimental evidence has upheld the likelihood of using mesenchymal stem cells or a bone marrow mononuclear cells (BMMC) pool to treat chronic lung diseases. For this purpose, several studies report the migration of adult (mesenchymal and hematopoietic) SCs to injured areas in lungs, which regenerate the pulmonary parenchyma. ${ }^{16-26}$

This evidence, along with other supporting information, have served as basis for proposing a protocol for the use of cell therapy in lung diseases. Therefore, this study has sought to evaluate the safety of the procedure of SCs infusion in patients with advanced COPD (stage IV dyspnea).

\section{Patients and methods}

\section{Patient selection}

This study was carried out at the Cardiovascular Diseases Institute in São José do Rio Preto, São Paulo, Brazil, from May 2009 to October 2009. Four patients (as approved by the Brazilian National Committee of Ethics in Research [CONEP], Brazil) with clinical and laboratory diagnosis of advanced pulmonary emphysema were enrolled in this study. Patients signed the Knowledge and Free Consent Instrument (TCLE) after receiving oral and written information that the procedure entailed possible risks and benefits. The clinical protocol, as well as the TCLE, developed for this study was registered with CONEP (registration no. 14764) in 2008. It was approved in April 2009 (report no. 233/2009) for application in 4 of a total of 10 patients requested in the original project sent to CONEP. The protocol has also been registered with ClinicalTrials. gov (NCT01110252).
Inclusion criteria were as follows: aged between 40 and 72 years, severe COPD, limited life expectancy, ineffective clinical treatments, limitation in daily physical activities, acceptable nutritional condition, acceptable cardiac function, satisfactory psychosocial and emotional profile and family support, possibility of pulmonary rehabilitation physiotherapy, and no tobacco use for at least 6 months before the protocol application, besides scoring higher than 3 according to the Modified Medical Research Council (MRC) Dyspnea Scale Score test. ${ }^{28,29}$

Exclusion criteria were as follows: active pulmonary or extrapulmonary infection, serious coronaropathy and/ or ventricular dysfunction, significant renal illness and/or hepatitis, detected immunosuppressive illnesses, smoking habit, carrier of known neoplasias, pregnancy, lack of family support, psychosocial problems, drug or alcohol abuse, and noncompliance with established medical protocol.

\section{Clinical evaluation and complementary laboratory tests in the preprocessing phase}

In the preprocessing phase, patients underwent a complete evaluation of the pulmonary function with bronchodilator, cardiopulmonary test I, determination of residual volume and pulmonary diffusion capacity, cardiac evaluation (clinical examination, echocardiography, and electrocardiography), chest X-ray, chest computed tomography scan (helical/high resolution), scintigraphic ventilation/perfusion, as well as routine laboratory tests (blood gas, urinalysis, coagulation, complete blood count (CBC), blood urea nitrogen, fasting glucose, creatinine, C-reactive protein, serology for hepatitis $\mathrm{B}$ and $\mathrm{C}$, antihuman immunodeficiency virus, and treponemal test for syphilis (FTA-ABS)). The Dyspnea Scale Score test, modified according to the British MRC, was also conducted, according to Mahler and Wells ${ }^{28}$ and Curley. ${ }^{29}$

\section{Stimulation with G-CSF}

Patients received a dose of granulocyte colony-stimulating factor (G-CSF) (Filgrastin ${ }^{\mathrm{TM}}$; Laboratório Aché, Guarulhos, São Paulo, Brazil) at $5 \mu \mathrm{g} / \mathrm{kg}$ by subcutaneous injection $(13 \times 4.5$ needle $)$ in the back of the arm for three consecutive days before the bone marrow harvest to stimulatie the production and release of hematopoietic SCs, as reported by Koca and Champlin. ${ }^{30}$

\section{Harvest of SCs}

Patients were taken to the operating room, placed in a prone position, and administered a spinal anesthesia. During the 
whole procedure, the individuals were maintained on nasal oxygen catheter $(2 \mathrm{~L} / \mathrm{min}$ ) and monitored (pulse oximeter, blood pressure, and electrocardiogram).

A total of 20 (10 on each iliac crest) punctures was made, always in different parts, with a Jamshidi needle (PharmasealTM; Baxter Healthcare Corporation, Valencia, CA). Approximately, $10 \mathrm{~mL}$ of bone marrow were aspirated from each puncture, using a $20-\mathrm{mL}$ syringe previously filled with $0.5 \mathrm{~mL}$ of heparin sodium $(5000 \mathrm{IU} / \mathrm{mL})$ (Roche; Rio de Janeiro, Brazil). The collected material was added to a Baxter ${ }^{\mathrm{TM}}$ (Baxter Healthcare Corporation) collection bag. The clamps of the collection kit were opened and the bone marrow total content was filtered by gravity.

\section{Preparation of the SCs}

The collection bag packed in a sterile field was opened inside a laminar flow hood. The collection bag content was collected with the aid of a coupler, in strictly aseptic conditions. Inside the laminar flow, $20 \mathrm{~mL}$ of Ficoll-Hypaque Premium $^{\mathrm{TM}}$ (GE Healthcare, Uppsala, Sweden) were placed in polypropylene centrifuge tubes of $50 \mathrm{~mL}$ (Corning TM; São Paulo, Brazil) and then $30 \mathrm{~mL}$ of bone marrow (diluted 1:1 with saline) were added, to give a total a volume of $50 \mathrm{~mL}$ inside the tube with the Ficoll-Hypaque Premium solution. Afterward, the tubes were centrifuged at $300 \mathrm{~g}$ for $30 \mathrm{~min}$ at $18^{\circ} \mathrm{C}$.

The ring of mononuclear cells formed above the Ficoll layer was collected with the aid of a sterile Pasteur pipette. Then, the mononuclear cells were transferred to other $50 \mathrm{~mL}$ centrifuge tubes. The volume was completed with RPMI culture medium (Cultilab, Campinas, Brazil). These tubes were centrifuged at $300 \mathrm{~g}$ for $15 \mathrm{~min}$ at $18^{\circ} \mathrm{C}$. After centrifugation, the supernatant was discarded. The precipitate was resuspended in RPMI culture medium. The contents of all the tubes were aggregated and then centrifuged at $300 \mathrm{~g}$ at $18^{\circ} \mathrm{C}$ for $10 \mathrm{~min}$. At the end of this step, the precipitate was resuspended to a final volume of $\sim 50 \mathrm{~mL}$ with albumin saline solution (ASS) aiming for two parameters: volume $(50 \mathrm{~mL})$ and final concentration of $1 \times 10^{8}$ mononuclear cells $/ \mathrm{mL}$. The total volume was filtered in a Cell StrainerTM (BD Falcon, San Jose, CA) with a porosity of $100 \mu \mathrm{m}$ to remove any impurities, cellular aggregates, and/or bone fragments.

Two counts with Turk's solution and trypan blue were performed: the first count after the collection of bone marrow and the second count after the processing of the cells.

\section{SCs infusion}

The infusion was made into a (medial brachial) peripheral vein, promptly after the preparation, separation, and counting of the mononuclear cells. The mononuclear cells (BMMC) pool solution, diluted in physiological serum at 5\% albumin (ASS) to a final volume of $30 \mathrm{~mL}$, was slowly infused, over $\sim 20 \mathrm{~min}$. The study design of this clinical trial is schematically presented in Figure 1 .

\section{Clinical progress}

Consultations and clinical-ambulatory follow-ups were scheduled for a total of six appointments for tests conduction and analysis of the patients' clinical progress, as shown in Table 1.

The schedule as shown in Table 2 was followed, except for those conditions in which a specific clinical evaluation recommended making urgent examinations.

\section{Statistical analysis}

The project originally sent to the National Committee of Ethics in Research (CONEP-Brazil) demanded an initial sample of 10 patients. This sample size would allow a statistical analysis by using nonparametric tests (Wilcoxon test). However, the protocol was approved for the study of only

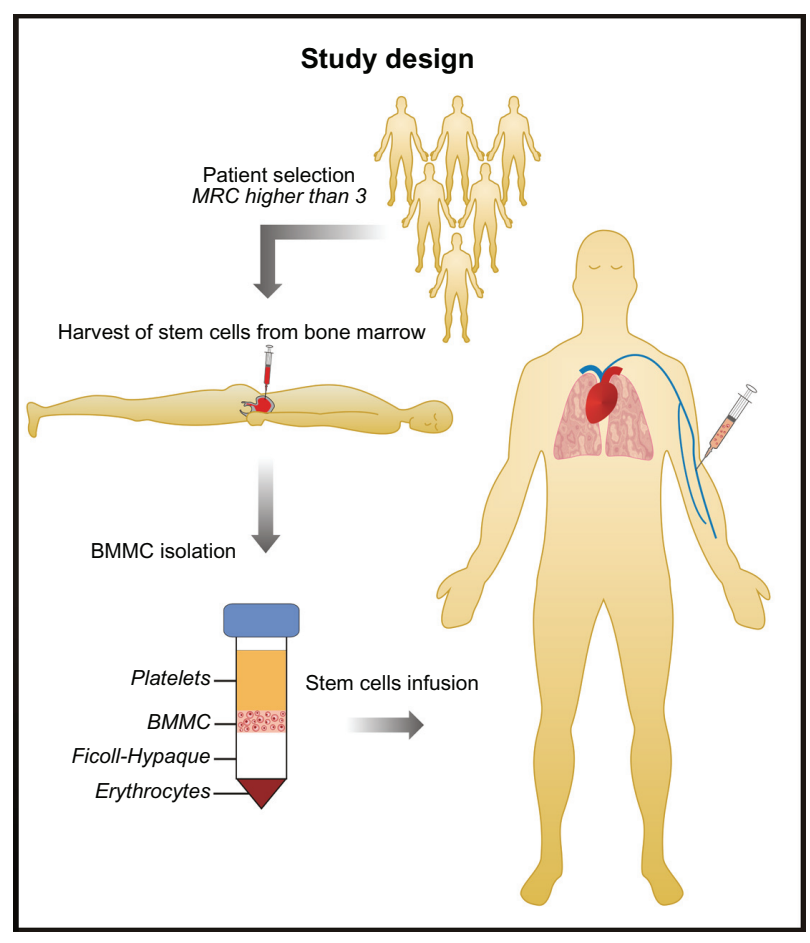

Figure I Study design adopted for this unicentric clinical trial of cellular therapy in chronic obstructive pulmonary disease - pulmonary emphysema.

Abbreviations: BMMC, bone marrow mononuclear cells; MRC, Modified Medical Research Council [Dyspnea Scale]. 
Table I Patients' follow-up: laboratory tests frequency in relation to procedure date

- Visit I-7 days

- Visit 2-I month

- Visit 3-2 months

- Visit 4-3 months

- Visit 5-6 months

- Visit 6-12 months

four patients. Given the smaller sample size, the originally proposed test could not be conducted.

\section{Results}

The age of selected patients ranged from 59 to 76 years, and all were males with advanced COPD (stage IV dyspnea). Smoking habit for at least 20 years was a common feature for all patients, and furthermore, all had quit smoking 10 years ago. All cases reported dyspnea at minimum exertions and chronic $\mathrm{O}_{2}$ dependence by nasal catheter. Table 3 shows in summary the general data of the four patients submitted to the BMMC infusion procedure.

Generally speaking, the laboratory parameters were consistent with clinical normality and acceptability. The chief results which lead to conclusions and extrapolations are shown and discussed. The results of echocardiogram analysis of patients IMC 001, IMC 002, and IMC 003 did not show serious impairment of systolic and diastolic functions; only patient IMC 004 showed a mild degree of mitral insufficiency. Likewise, the results of electrocardiogram analysis did not show significant changes. Computerized tomography validated the diagnoses of moderate and advanced pulmonary emphysema, with centrilobular being the predominant type, and occurrence of calcified pulmonary nodules.

Patient IMC 001 showed signs and symptoms due to the use of G-CSF, such as fever, nausea, indisposition, and small discomfort. After the BMMC pool infusion, no adverse reactions occurred that could be associated with cell therapy.

The partial results from spirometry analysis before and after the CT infusion are shown in Figures 2-4.

Patient IMC 001 showed improved clinical condition and a gradually reduced $\mathrm{O}_{2}$ intake by nasal catheter immediately after the procedure. However, in the long term, the progress was severely harmed by several complications, which were neither linked to the procedure nor presented by the other patients. Unquestionably, clinical and laboratory parameters showed that this patient had the most serious and advanced COPD condition. These continuous complications impaired the patient's progress and clinical follow-up. Some tests could not be conducted in this patient and, therefore, the laboratory results are not shown in the results.

The arterial blood gas tests carried out before and 30 days after the procedure are shown in Table 4 . The achieved results do not allow a precise analysis of the patients' possible laboratory improvement. Other than the small sample size of four patients, there are complications with respect to the arterial blood gas tests, such as the infection acquired by patient IMC 001 and the conduction of gas analysis without $\mathrm{O}_{2}$ by patient IMC 003 .

All patients received stimulation with the use of G-CSF in order to increase the number of SCs in the bone marrow. The hemogram analysis before and after the three doses of G-CSF showed a significant increase in the number of cells for all patients (data not shown). As this comparative analysis demonstrates, the increase in leucocytes may lead to an increase in young, undifferentiated cells, which proportionally decreases $\mathrm{CD} 133^{+}$cells and/or makes them undetectable (Table 5).

Table 2 Clinical and complementary examinations in the postprocedure phase

\begin{tabular}{|c|c|c|c|c|c|c|}
\hline \multirow[t]{2}{*}{ Clinical and laboratorial parameters } & \multicolumn{6}{|c|}{ Time in relation to the procedure date } \\
\hline & 7 days & I month & 2 months & 3 months & 6 months & 12 months \\
\hline Visit for clinical evaluation & $\times$ & $\times$ & $\times$ & $x$ & $\times$ & $\times$ \\
\hline Complete ventilation test with bronchodilator & & $\times$ & $\times$ & $\times$ & $\times$ & $\times$ \\
\hline Chest X-ray & & $\times$ & & & $\times$ & $\times$ \\
\hline Chest CT & & & & & & $\times$ \\
\hline Scintigraphy: inhalation/perfusion & & & & & & $\times$ \\
\hline Arterial blood gases & & $\times$ & & $\times$ & & $\times$ \\
\hline $\mathrm{CBC}$ & $\times$ & $\times$ & $\times$ & $\times$ & $\times$ & $\times$ \\
\hline CEA (tumor marker) & & & & & & $\times$ \\
\hline 6-min walking test (cardiopulmonary test I) & & $\times$ & $\times$ & $\times$ & $\times$ & $\times$ \\
\hline Dyspnea Scale Score & $\times$ & $x$ & $\times$ & $\times$ & $\times$ & $\times$ \\
\hline
\end{tabular}

Abbreviations: $\mathrm{CT}$, computed tomography; $\mathrm{CBC}$, complete blood count; $\mathrm{CEA}$, carcinoembryonic antigen. 
Table 3 General data of the procedures in the first four patients submitted to cell therapy for advanced pulmonary emphysema with pool of BMMC

\begin{tabular}{|c|c|c|c|c|c|c|c|c|}
\hline Patients & Sex & $\begin{array}{l}\text { Age } \\
\text { (years) }\end{array}$ & $\begin{array}{l}\text { COPD } \\
\text { score }\end{array}$ & $\begin{array}{l}\text { Procedure } \\
\text { date }\end{array}$ & $\begin{array}{l}\text { G-CSF } \\
\text { stimulation }\end{array}$ & $\begin{array}{l}\text { Bone marrow } \\
\text { harvested volume }(\mathrm{mL})\end{array}$ & $\begin{array}{l}\text { Infusion (BMMC) } \\
\text { volume }(\mathrm{mL})\end{array}$ & Venous access \\
\hline IMC 00I' & $M$ & 76 & IV & $11 / 05 / 09$ & 3 days & 151 & 30 & Brachial \\
\hline IMC 002 & $M$ & 64 & IV & 07/07/09 & 3 days & 200 & 30 & Brachial \\
\hline IMC 003 & $M$ & 59 & IV & $13 / 08 / 09$ & 3 days & 200 & 30 & Brachial \\
\hline IMC 004 & $M$ & 64 & IV & $01 / 10 / 09$ & 3 days & 202 & 30 & Brachial \\
\hline
\end{tabular}

Note: 'Patient presented continuous complications (repeated infections) that impaired the long-term clinical follow-up.

Abbreviations: BMMC, bone marrow mononuclear cells; COPD, Chronic Obstructive Pulmonary Disease; G-CSF, granulocyte colony-stimulating factor; M, male.

\section{Discussion}

The COPD cell therapy reported in this study refers to a Phase I clinical protocol. Its chief purpose was to evaluate the safety of the procedure. Even though the small approved sample size (four patients) does not allow for a reliable statistical analysis, inferences may be drawn in connection with relevant aspects, other than safety, such as the procedure efficacy and the incorporation of other methodological approaches.

By taking into account the accomplished results and the patients' clinical progress, it may be asserted that the methodology at issue for the collection and infusion of BMMC free of collateral effects. This important affirmation is essential for continuing and/or increasing the number of patients in

A

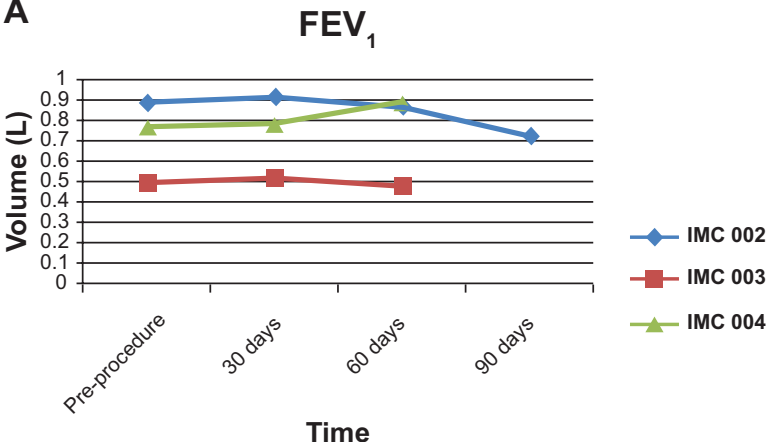

B Percentage of predicted FEV 1

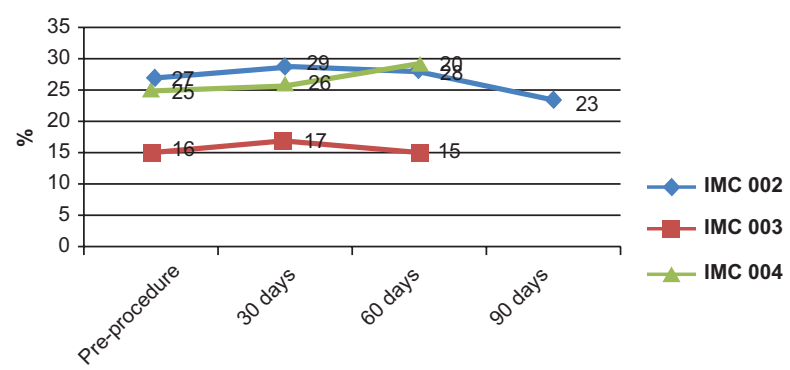

Figure 2 A) Forced expiratory volume in I sec $\left(\mathrm{FEV}_{1}\right)$. B) Percentage of predicted FEV, pre- and postprocedure, for IMC 002, IMC 003, and IMC 004 patients. future protocols, which may also address the introduction of new methodological approaches, such as the infusion form of the BMMC pool (directly into the pulmonary tissue), the increase of the bone marrow volume to be collected, and the infusion in repeated doses.

All the voluntary subjects showed improvement in their clinical condition. The complete reports suggest a greater time tolerance without $\mathrm{O}_{2}$ intake by nasal catheter, besides a greater capacity on exertion, without significant fall in saturation. The fact that this sensation of clinical improvement may be due to a mere placebo effect may not be excluded, which would easily explain the patient's response during the first days or even weeks after treatment; however, it would not justify the results after several months of laboratory and clinical follow-up.

A

A FVC

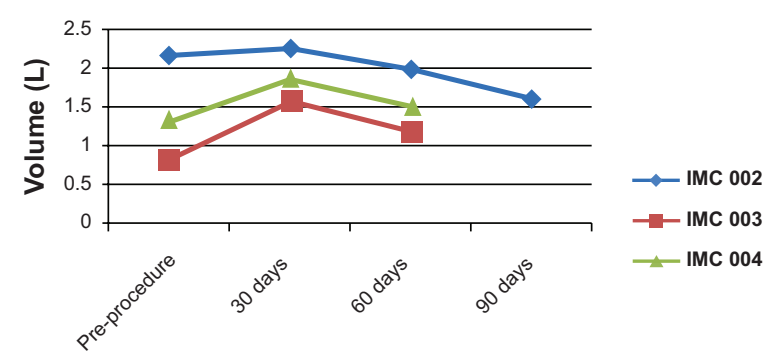

Time
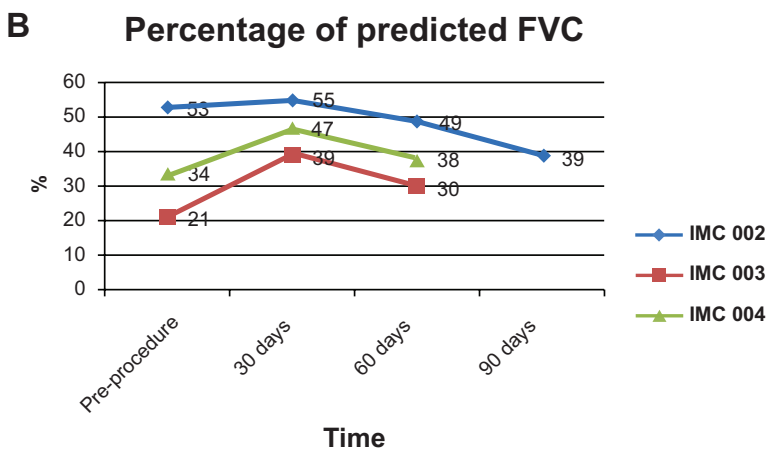

Figure 3 A) Forced vital capacity (FVC). B) Percentage of predicted FVC pre- and postprocedure. 


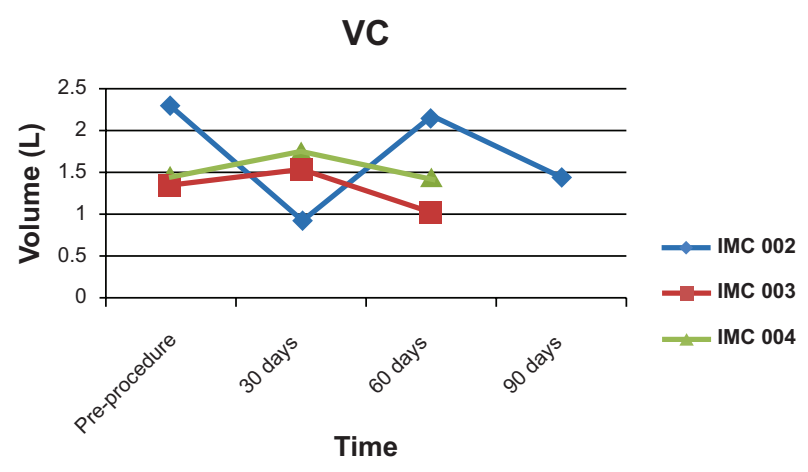

Figure 4 Vital capacity (VC) pre- and postprocedure.

The spirometry results from patients IMC 002, IMC 003, and IMC 004 indicate a very slight improvement, as shown in Figures 2-4. The results and analysis of patient IMC 001 were probably impaired by the unfavorable clinical progress, arising out of a spate of complications, such as pneumonia and infection. However, all the patients, especially patients IMC 002 and IMC 003, showed a significant improvement in their psychological condition and quality of life.

Patient IMC 002 is worth a special analysis, because his clinical response was the most successful. He prolonged his walking distance and walking time without important dyspnea. He reported a significant recovery with pronounced improvement in his quality of life and psychological condition. An extremely relevant aspect is the need to include a questionnaire to compare between the quality of life before and after the procedure.

The FEV 1 laboratory analysis showed an improvement in all patients after 30 days. Later, patient IMC 002 presented a progressive decrease, which was associated to a condition of airways infection (Figure 2). There was continuation of the values of patient IMC 003 and a considerable improvement in IMC 004. Likewise, the increase in forced vital capacity (FVC) and vital capacity (VC) parameters was verified in all patients after 30 days following procedure (Figures 3 and 4); however, after this period, FVC decreased. An important aspect refers to the values which were constantly higher than the values found before the procedure. Only patient
IMC 002 showed a sharper decrease in the values during examination as a result of his infectious clinical condition, and he presented changes in connection with the VC parameter. Generally speaking, the evaluated parameters demonstrate laboratory improvement and infer the possibility of alveolar regeneration without change in the pulmonary tissue elasticity.

The preliminary results of this clinical study suggest that the procedure must be completed in a less advanced stage of pulmonary emphysema. This is upheld by previous work. Voltarelli et al ${ }^{31}$ made a prospective study in 15 newly diagnosed patients with type 1 diabetes mellitus in the asymptomatic stage ( $<6$ weeks). The patients were submitted to the autologous nonmyeloablative hematopoietic SC transplantation. The results showed that, of the 15 patients who underwent the treatment, 14 patients became insulinfree for a period and only one patient did not respond to the therapy. Other work has also demonstrated that the use of SCs in the treatment of several pathologies, such as rheumatic illness, lupus nephritis, systemic lupus erythematosus, ovarian cancer, multiple sclerosis, Hodgkin's disease, and myocardiopathies, has shown greater effectiveness when $\mathrm{SC}$ therapy is instituted in patients in less advanced stages of the disease. ${ }^{32-39}$

According to the National Agency of Sanitary Surveillance (ANVISA RDC resolution 153/2004), ${ }^{40}$ the total blood volume to be aspirated from bone marrow cannot exceed $9 \mathrm{~mL} /$ $\mathrm{kg}$ of body weight for men and $8 \mathrm{~mL} / \mathrm{kg}$ of body weight for women. In compliance with this resolution, from a $70-\mathrm{kg}$ male patient, for example, a bone marrow volume of up to $630 \mathrm{~mL}$ could be collected. In this study, the collected volume from each patient ranged from 150 to $200 \mathrm{~mL}$. CD133 ${ }^{+}$cells were only detected in patient IMC 003 , precisely the patient who presented, according to data in Table 2, the highest NC number and highest BMMC recovery. By virtue of the very restricted sample size, these data do not allow a definite conclusion, but they advance the possibility that the bone marrow volume to be collected should be considerably higher than that adopted in this protocol. Therefore, the proposition for harvesting a higher

Table 4 Results of arterial blood gases tests pre- and postprocedure

\begin{tabular}{|c|c|c|c|c|c|c|c|c|c|}
\hline & \multicolumn{2}{|c|}{ IMC 00 I } & \multicolumn{2}{|c|}{ IMC 002} & \multicolumn{2}{|c|}{ IMC 003} & \multicolumn{2}{|c|}{ IMC 004} & \multirow[t]{2}{*}{ Benchmarks } \\
\hline & Pre & Post & Pre & Post & Pre & Post $^{\prime}$ & Pre & Post & \\
\hline $\mathrm{PaCO}_{2}(\mathrm{~mm} \mathrm{Hg})$ & 81 & 45 & 39 & 41 & 35 & 52 & 40 & 37 & $36-46$ \\
\hline $\mathrm{PaO}_{2}(\mathrm{~mm} \mathrm{Hg})$ & 51 & 65 & 60 & 58 & 97 & 45 & 68 & 60 & $80-100$ \\
\hline $\mathrm{O}_{2}$ content $(\%)$ & 82 & 92 & 91 & 90 & 98 & 83 & 94 & 92 & $92-96$ \\
\hline
\end{tabular}

Note: 'Without nasal oxygen catheter.

Abbreviations: $\mathrm{PaCO}_{2}$, PaCO, . 
Table 5 Cell concentration and characterization of some markers from mononuclear cells pool before (pre) and after (post) processing for infusion into patients

\begin{tabular}{|c|c|c|c|c|c|c|c|c|}
\hline \multirow[t]{2}{*}{ Patients } & \multicolumn{2}{|c|}{$\mathrm{NC}\left(\times \mid 0^{8}\right)$} & \multicolumn{2}{|c|}{ BMMC $\left(\times 10^{8}\right)$} & \multicolumn{2}{|c|}{$\mathrm{CD}_{3} 4^{+}\left(\times 10^{6}\right)$} & \multicolumn{2}{|c|}{ CDI33+ $\left(\times 10^{6}\right)$} \\
\hline & Pre & Post & Pre & Post & Pre & Post & Pre & Post \\
\hline IMC 001 & 0.55 & 0.09 & 0.05 & 0.03 & 0.05 & 0.05 & 0.0 & 0.0 \\
\hline IMC 002 & 0.79 & 0.12 & 0.18 & 0.04 & 0.43 & 0.10 & 0.0 & 0.0 \\
\hline IMC 003 & 1.23 & 0.34 & 0.22 & 0.14 & 0.20 & 0.23 & 0.01 & 0.01 \\
\hline IMC 004 & 0.89 & 0.12 & 0.14 & 0.046 & 0.21 & 0.15 & 0.0 & 0.0 \\
\hline
\end{tabular}

Abbreviations: Pre and post, pre- and postcell processing values; NC, nuclear cells; BMMC, bone marrow mononuclear cells.

bone marrow volume is based on the above considerations, that is: 1) the feasibility and safety of collecting a higher volume of material, as carried out in hematopoietic SC transplantation, and 2) the logical inference that a higher aspirated bone marrow volume results, proportionally, at the end of the process and adult $\mathrm{SC}$ separation in a significant higher number of $\mathrm{CD} 133^{+}$ cells. Therefore, this item should be reviewed and possibly changed in future studies.

It is important to emphasize, in the bone marrow source autologous therapy, that G-CSF, a hematopoietic growth factor which stimulates the proliferation and mobilization of bone marrow hematopoietic cells to the peripheral blood, ${ }^{41-45}$ has been used in cell therapy procedures in both animal and human models. ${ }^{46-51}$ The rationale for its use in this study was related to previous results showing that this drug determines an increase in myeloid progenitor cells and CD34 $4^{+}$cells. ${ }^{41,52}$ However, as can be seen in Table 3, G-CSF did not induce the proliferation of cell lines $\mathrm{CD} 34^{+}$and $\mathrm{CD} 133^{+}$, which are possibly involved in the regeneration of damage tissues. ${ }^{53-55}$ Therefore, its application may be dispensed upon attaining cells with direct bone marrow puncture.

The results obtained indicate that the methodology used for BMMC pool cell therapy in emphysema patients is quite safe, without any significant adverse effects and/or that could mean a risk to patients. The laboratory analysis, confirmed by clinical response, reported a slight improvement in all patients, chiefly in the first 30 days after the procedure was carried out. After this period, laboratory tests displayed a tendency to decrease; however, they did not drop to the base values obtained before the BMMC therapy. These results indicate the possibility that cell therapy may be applied long term for the purpose of stimulating pulmonary regeneration.

Considering the small sample size of patients, the results do not support definite conclusions, but they provide indications and allow the postulation of the need for new alternatives and methodological adjustments in the adopted protocol. Among the proposals for methodological adjustment that may be considered in future studies, the following should be included: a questionnaire to analyze the patients' quality of life; increasing the bone marrow volume to be harvested (300-400 mL); omitting the use of G-CSF as an inducer of cell proliferation and feasibility of chronic therapeutics through repeated doses; changing the inclusion criteria, by enrolling patients with less advanced pulmonary emphysema.

\section{Acknowledgments}

The authors thank the Foundation for Development of UNESP (Fundunesp), Assis City Hall (SP, Brazil) and CIVAP/Health. The authors also thank Ana Carolina de Abreu for the assistance in the elaboration of the consent term. This study has not received external funding and was financially supported by Cardiovascular Disease Institute (IMC, São José do Rio Preto, SP, Brazil), where this clinical trial was performed. Carolina A de Faria and Monica Y Marcelino were financially supported by CAPES (Inter-units Biotechnology Post Graduation Program (USP) institutional grant).

\section{Disclosure}

The authors report no conflicts of interest in this work.

\section{References}

1. World Health Organization. Global alliance against chronic respiratory diseases (GARD). General Meeting Report; Istanbul, Turkey. 2008 May; 30-31.

2. Global Initiative for Chronic Obstructive Lung Disease. Global Strategy for Diagnosis, Management, and Prevention of COPD; 2009. Available from: http://www.goldcopd.com/. Updated 2009 Dec. Accessed Dec 3 2010 .

3. Murray CJ, Lopez AD. Mortality by cause for eight regions of the world: Global Burden of Disease Study. Lancet. 1997;349(9061): 1269-1276.

4. Campos HS. O preço da DPOC. Pulmão RJ. 2004;13(1):5-7.

5. Lopez AD, Shibuya K, Rao C, et al. Chronic obstructive pulmonary disease: current burden and future projections. Eur Respir J. 2006;27(2): 397-412.

6. Barnes PJ, Shapiro SD, Pauwels RA. Chronic obstructive pulmonary disease: molecular and cellular mechanisms. Eur Respir J. 2003;22(4): $672-688$. 
7. Jardim JR, de Oliveira JA, Nascimento O. II Consenso Brasileiro sobre Doença Pulmonar Obstrutiva Crônica (DPOC). J Bras Pneumol. 2004;30 Suppl 5:S1-S42.

8. Gross P, Pfitzer EA, Tolker E, Babyak MA, Kaschak M. Experimental emphysema: its production with papain in normal and silicotic rats. Arch Environ Health. 1965;11:50-58.

9. Martorana PA, van Even P, Gardi C, Lungarella G. A 16-month study of the development of genetic emphysema in tight-skin mice. Am Rev Respir Dis. 1989;139(1):226-232.

10. Hyatt RE, Farkas G, Schroeder M. Pulmonary mechanics of papain emphysema in dogs. Chest. 2000;117(5 Suppl 1):246S-247S.

11. Fusco LB, Pêgo-Fernandes PM, Xavier AM, et al. Modelo experimental de enfisema pulmonar em ratos induzido por papaína. J Pneumol. 2002; 28(1):1-7.

12. Hele D. First Siena International Conference on animal models of chronic obstructive pulmonary disease, Certosa di Pontignano, Universidade of Siena, Italy, 2001 Sep 30-Oct 2. Respir Res. 2002;3:12.

13. Mahadeva R, Shapiro SD. Chronic obstructive pulmonary disease *3: experimental animal models of pulmonary emphysema. Thorax. 2002;57(10):908-914.

14. Nikula KJ, March TH, Seagrave J, et al. A mouse model of cigarette smoke-induced emphysema. Chest. 2000;117(5 Suppl 1):246S-247S.

15. Cazzola M, Donner CF, Hanania NA. One hundred years of chronic obstructive pulmonary disease (COPD). Respir Med. 2007;101(6): 1049-1065.

16. Weiss DJ, Kolls JK, Ortiz LA, Panoskaltsis-Mortari A, Prockop DJ. Stem cells and cell therapies in lung biology and lung diseases. Proc Am Thorac Soc. 2008;5(5):637-667.

17. Ribeiro-Paes JT, Bilaqui A, Greco OT, et al. Terapia celular em doenças pulmonares: existem perspectivas? Rev Bras Hematol Hemoter. 2009;31 Suppl 1:140-148.

18. Sueblinvong V, Weiss DJ. Stem cells and cell therapy approaches in lung biology and diseases. Transl Res. 2010;156(3):188-205.

19. Bittmann I, Dose T, Baretton GB, et al. Cellular chimerism of the lung after transplantation. An interphase cytogenetic study. Am J Clin Pathol. 2001;115(4):525-533.

20. Kotton DN, Ma BY, Cardoso WV, et al. Bone marrow-derived cells as progenitors of lung alveolar epithelium. Development. 2001;128(24): 5181-5188.

21. Krause DS, Theise ND, Collector MI, et al. Multi-organ, multilineage engraftment by a single bone marrow-derived stem cell. Cell. 2001;105(3):369-377.

22. Suratt BT, Cool CD, Serls AE, et al. Human pulmonary chimerism after hematopoietic stem cell transplantation. Am J Respir Crit Care Med. 2003;168(3):318-322.

23. Neuringer IP, Randell SH. Stem cells and repair of lung injuries. Respir Res. 2004;5:6.

24. Yamada M, Kubo H, Kobayashi S, et al. Bone marrow-derived progenitor cells are important for lung repair after lipopolysaccharide-induced lung injury. J Immunol. 2004;172(2):1266-1272.

25. Lama VN, Smith L, Badri L, et al. Evidence for tissue-resident mesenchymal stem cells in human adult lung from studies of transplanted allografts. J Clin Invest. 2007;117(4):989-996.

26. Schrepfer S, Deuse T, Reichenspurner H, Fischbein MP, Robbins RC, Pelletier MP. Stem cell transplantation: the lung barrier. Transplant Proc. 2007;39(2):573-576.

27. Agostini C. Stem cell therapy for chronic lung diseases: hope and reality. Respir Med. 2010;104 Suppl 1:S86-S91.

28. Mahler DA, Wells CK. Evaluation of clinical methods for rating dyspnea. Chest. 1988;93(3):580-586.

29. Curley FJ. Dyspnea. In: Irwin RS, Curley FJ, Grossman RF, editors. Diagnosis and Treatment of Symptoms of the Respiratory Tract. Armonk, NY: Future Publishing; 1997:56-115.

30. Koca E, Champlin RE. Peripheral blood progenitor cell or bone marrow transplantation: controversy remains. Curr Opin Oncol. 2008;20(2):220-226.
31. Voltarelli JC, Couri CEB, Stracieri ABPL, et al. Autologous nonmyeloablative hematopoietic stem cell transplantation in newly diagnosed type 1 diabetes mellitus. JAMA. 2007;297(14):1568-1576.

32. Stiff PJ, Veum-Stone J, Lazarus HM, et al. High-dose chemotherapy and autologous stem-cell transplantation for ovarian cancer: an autologous blood and marrow transplant registry report. Ann Intern Med. 2000; 133(7):504-515.

33. Sureda A, Arranz R, Iriondo A, et al. Autologous stem-cell transplantation for Hodgkin's disease: results and prognostic factors in 494 patients from the Grupo Espanõl de Linfomas/Transplante Autólogo de Médula Osea Spanish Cooperative Group. J Clin Oncol. 2001;19(5): $1395-1404$.

34. Voltarelli JC, Stracieri ABPL, de Oliveira MCB, et al. Transplante autólogo de células tronco hematopoéticas para nefrite lúpica: resultados brasileiros iniciais. J Bras Nefrol. 2003;25(2):65-72.

35. Voltarelli JC. Transplante de células-tronco hematopoéticas no diabete melito do tipo I. Rev Bras Hematol Hemoter. 2004;26(1):43-45.

36. Burt RK, Cohen B, Rose J, et al. Hematopoietic stem cell transplantation for multiple sclerosis. Arch Neurol. 2005;62(6):860-864.

37. Voltarelli JC, Stracieri ABPL, Oliveira MCB, et al. Transplante de células-tronco hematopoéticas em doenças reumáticas. Parte 1: experiência internacional. Rev Bras Reumatol. 2005;45(4):229-241.

38. Burt RK, Traynor A, Statkute L, et al. Nonmyeloablative hematopoietic stem cell transplantation for systemic lupus erythematosus. JAMA. 2006;295(5):527-535.

39. Chachques JC. Cellular cardiac regenerative therapy in which patients? Expert Rev Cardiovasc Ther. 2009;7(8):911-919.

40. BRASIL. Resolução RDC no 153, de 14 de junho de 2004. Determina o Regulamento Técnico para os procedimentos hemoterápicos, incluindo a coleta, o processamento, a testagem, o armazenamento, o transporte, o controle de qualidade e o uso humano de sangue, e seus componentes, obtidos do sangue venoso, do cordão umbilical, da placenta e da medula óssea. D.O.U. - Diário Oficial da União; Poder Executivo, de 24 de junho de 2004.

41. Slowman S, Danielson C, Graves V, Kotylo P, Broun R, McCarthy L. Administration of GM-/G-CSF prior to bone marrow harvest increases collection of CD34+ cells. Prog Clin Biol Res. 1994;389:363-369.

42. Dicke KA, Hood DL, Arneson M, et al. Effects of short-term in vivo administration of G-CSF on bone marrow prior to harvesting. Exp Hematol. 1997;25(1):34-38.

43. Isola LM, Scigliano E, Skerrett D, et al. A pilot study of allogeneic bone marrow transplantation using related donors stimulated with G-CSF. Bone Marrow Transplant. 1997;20(12):1033-1037.

44. Dahl E, Burroughs J, DeFor T, Verfaillie C, Weisdorf D. Progenitor content of autologous grafts: mobilized bone marrow vs mobilized blood. Bone Marrow Transplant. 2003;32(6):575-580.

45. Levesque JP, Winkler IG. Mobilization of hematopoietic stem cells: state of the art. Curr Opin Organ Transplant. 2008;13(1):53-58.

46. Frangoul H, Nemecek ER, Billheimer D, et al. A prospective study of G-CSF primed bone marrow as a stem-cell source for allogeneic bone marrow transplantation in children: a Pediatric Blood and Marrow Transplant Consortium (PBMTC) study. Blood. 2007;110(13):4584-4587.

47. Pusic I, DiPersio JF. The use of growth factors in hematopoietic stem cell transplantation. Curr Pharm Des. 2008;14(20):1950-1961.

48. Hokari M, Kuroda S, Chiba Y, Maruichi K, Iwasaki Y. Synergistic effects of granulocyte-colony stimulating factor on bone marrow stromal cell transplantation for mice cerebral infarct. Cytokine. 2009;46(2): 260-266.

49. Greinix HT, Worel N. New agents for mobilizing peripheral blood stem cells. Transfus Apher Sci. 2009;41(1):67-71.

50. Ripa RS, Jørgensen E, Wang Y, et al. Stem cell mobilization induced by subcutaneous granulocyte-colony stimulating factor to improve cardiac regeneration after acute ST-elevation myocardial infarction: result of the double-blind, randomized, placebo-controlled stem cells in myocardial infarction (STEMMI) trial. Circulation. 2006;113(16): 1983-1992. 
51. Zubair AC, Malik S, Paulsen A, et al. Evaluation of mobilized peripheral blood CD34(+) cells from patients with severe coronary artery disease as a source of endothelial progenitor cells. Cytotherapy. 2010;12(2):178-189.

52. Johnsen HE, Jensen L, Gaarsdal E, Hansen PB, Ersbøll J, Hansen NE. Priming with recombinant human hematopoietic cytokines before bone marrow harvest expands in vivo and enhances ex vivo recovery of myeloid progenitors in short-term liquid cultures. Exp Hematol. 1994; 22(1):80-86.
53. Jin H, Aiyer A, Su J, et al. A homing mechanism for bone marrowderived progenitor cell recruitment to the neovasculature. J Clin Invest. 2006;116(3):652-662.

54. Mizrak D, Brittan M, Alison MR. CD133: molecule of the moment. J Pathol. 2008;214(1):3-9.

55. Huertas A, Testa U, Riccioni R, et al. Bone marrow-derived progenitors are greatly reduced in patients with severe COPD and low-BMI. Respir Physiol Neurobiol. 2010;170(1):23-31.

International Journal of COPD

\section{Publish your work in this journal}

The International Journal of COPD is an international, peer-reviewed journal of therapeutics and pharmacology focusing on concise rapid reporting of clinical studies and reviews in COPD. Special focus is given to the pathophysiological processes underlying the disease, intervention programs, patient focused education, and self management protocols.

\section{Dovepress}

This journal is indexed on PubMed Central, MedLine and CAS. The manuscript management system is completely online and includes a very quick and fair peer-review system, which is all easy to use. Visit $\mathrm{http}: / /$ www.dovepress.com/testimonials.php to read real quotes from published authors.

Submit your manuscript here: http://www.dovepress.com/international-journal-of-copd-journal 